\title{
HIGH-INTENSITY CESIUM ION BEAMS FOR HIBP DIAGNOSTICS
}

\author{
L.I. Krupnik, J. Barcala ${ }^{2}$, O.O. Chmyga ${ }^{1}$, G.M. Deshko ${ }^{1}$, M.A. Drabinskiy ${ }^{3}$, L.G. Eliseev ${ }^{3}$, \\ C. Hidalgo ${ }^{2}$, Ph.O. Khabanov ${ }^{3}$, N.K. Kharchev ${ }^{3}$, S.M. Khrebtov ${ }^{1}$, O.D. Komarov ${ }^{1}$, \\ O.S. Kozachok , A.V. Melnikov ${ }^{3,4}$, A. Molinero ${ }^{2}$, J.L. de Pablos ${ }^{2}$, and TJ-II team ${ }^{2}$ \\ ${ }^{1}$ Institute of Plasma Physics NSC "Kharkov Institute of Physics and Technology", Kharkiv, Ukraine; \\ ${ }^{2}$ Fusion National Laboratory, CIEMAT, Madrid, Spain; \\ ${ }^{3}$ NRC "Kurchatov Institute", Moscow, Russia; \\ ${ }^{4}$ National Research Nuclear University "MEPhI”, Moscow, Russia \\ E-mail: hibp@kipt.kharkov.ua
}

\begin{abstract}
The goal of the research is to expand the capabilities of the heavy ion beam probing (HIBP) diagnostic. HIBP is a unique diagnostic, capable to measure plasma potential, density and their fluctuations, as well as the poloidal magnetic field fluctuations in the core and edge plasmas. The sensitivity of the diagnostic is determined by the level of the output signal related to the instrumental noise. The level of the probing beam current should be as high as possible, especially for measurements at the periphery with low output signal due to low plasma density, and in the core, where the beam is attenuated due to the high plasma density. Optimization experiments have shown the possibility of ion beam forming in the current range from 40 to $800 \mu \mathrm{A}$.
\end{abstract}

PACS: $52.70 . \mathrm{Nc}, 52.55 . \mathrm{Hc}$

\section{INTRODUCTION}

The active corpuscular diagnostics takes one of the leading places among the methods of plasma diagnostics. Plasma probing by heavy ion beams makes it possible to obtain information on the spatial distribution of plasma potential, density, their fluctuations and poloidal magnetic field fluctuations in the plasma of modern fusion devices.

$\mathrm{Cs}^{+}$primary ion beam of HIBP diagnostic is injected into the plasma, and the secondary ions $C s^{2+}$ created due to collisions with plasma electrons and separated from the primary beam by confining magnetic field are detected outside the plasma device by the energy analyzer [1]. The characteristics of the secondary probing ions (beam current, energy, and position) present the input data for plasma potential, density and magnetic field determination. The spatial profiles of the plasma parameters are obtained by variation of the primary beam entrance angle into the plasma [2].

The experiments were carried out with HIBP diagnostics on the TJ-II and "Uragan-2M" stellarators, which have practically identical injection systems, both elaborated in IPP NSC KIPT and operated with $\mathrm{Cs}^{+}$ probing beams $[3,4]$. Fig. 1 shows the schematic of the HIBP diagnostic on "Uragan-2M". HIBP consists of two main parts: the probing (primary) beam injector and the energy analyzer for secondary ions. The main task of the injector is the formation of the beam with optimal size (diameter) and current density in the area of the secondary ionization in plasma, or sample volume (SV). The $\mathrm{Cs}^{2+}$ beam current is proportional to the primary one. Experiments on a primary $\mathrm{Cs}^{+}$beam formation were carried out on injectors of diagnostic systems of the TJ-II and "Uragan-2M". In these experiments highintensity solid-state thermoionic emitters with a current density of up to $1.4 \mathrm{~mA} / \mathrm{cm}^{2}$ in the same design of the emitter-extractor units were used.

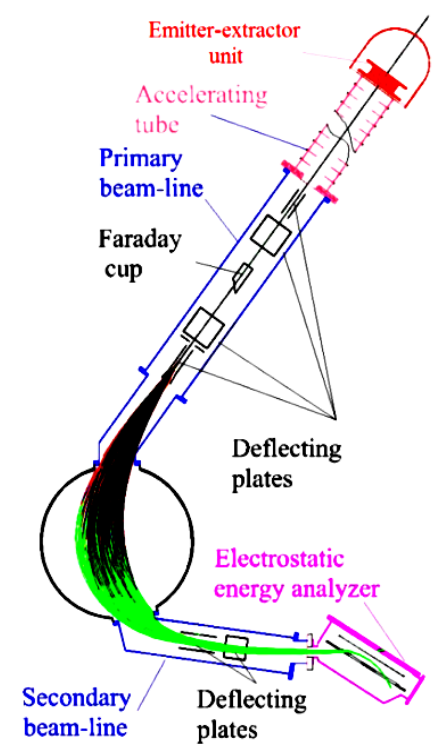

Fig. 1. HIBP schematic on the "Uragan-2M" stellarator. Beam trajectories: black-primary $\mathrm{Cs}^{+}$; green-secondary $\mathrm{Cs}^{2+}$

\section{PROBING BEAM OPTIMIZATION}

The aim of this work is to form the probing ion beam with minimal diameter at the given simple volume with a fixed level of the primary beam current. Traditionally in our injectors, the beam current and the focal distance were controlled by changing of two parameters: the heating power of the thermoionic emitter and the extraction voltage that also acted as a focusing voltage. This traditional schematic was not able to provide a reliable ion beam current in a series of experiments, long enough to make systematic studies.

Many years of experience on the HIBP operation in TM-4, T-10 and "Tuman-3M" tokamaks and "Uragan2M", TJ-II, and WEGA stellarators show that for 
various plasma densities and measurement areas, it is necessary to keep the maximum possible secondary ion current on the beam detector of the energy analyzer (signal-to-noise ratio) [5].

To maximize the beam current, the traditional injector was modernized and tuned as shown in Fig. 2.

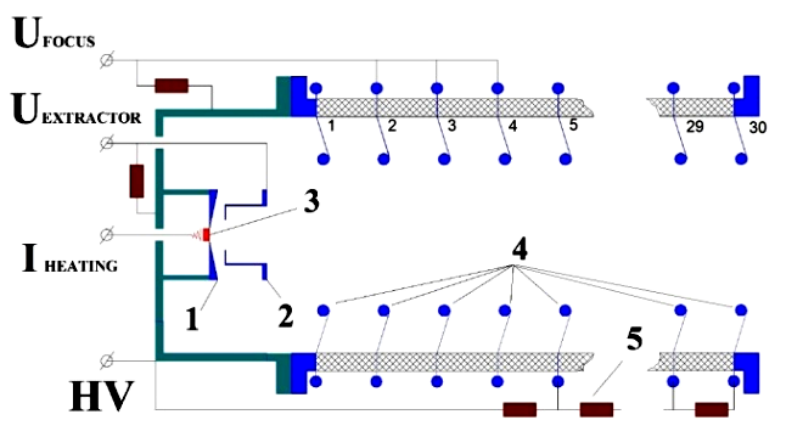

Fig. 2. Schematic of the optimized injector: Pierce 1 -electrode; 2 -extractor electrode; 3 -emitter;

4 - accelerating tube electrodes; 5 - accelerating tube divider resistors

This circuit has an additional focusing electrode and separated power supply to control the focusing voltage. Updated design was used for elaboration of the unified HIBP injectors on TJ-II and "Uragan-2M", where focusing voltage $U_{\text {focus }}$ is applied to the electrodes (\# 2-4) of the accelerating tube. The commercial power supply "Glassman-HV" $-10 \mathrm{kV}, 1.5 \mathrm{~mA}$ was used in both HIBPs.

This makes it possible to set the required level of the ion current by controlling the emitter heating power $P_{\text {heat }}$ and the extraction voltage, and focusing the beam at a desired area using a focusing voltage. To be able to work with ion beam currents of several hundred microamperes, solid-state thermoionic emitters [6] with increased material adhesion to the substrate were used. This is necessary for applying a heating power of the emitter up to $130 \mathrm{~W}$, which can cause peeling of the emitter material from the tantalum base. Such emitters with diameter $8.5 \mathrm{~mm}$, the working material mass of up to $250 \mathrm{mg}$ and high adhesion were developed at IPP NSC KIPT. Fig. 3 shows the voltage-current characteristics for different $P_{\text {heat }}$ and the curve of the Child-Langmuir law for the plane case.

The first experiments on the formation of highintensity cesium ion beam were carried out in 2016-2017 on the HIBP injector of "Uragan-2M".The main goal of the experiments was obtaining the minimal beam diameter for a wide range of ion currents. Fig. 4 shows the arrangement of the elements for registration and control of the ion beam in the primary HIBP beam line on the "Uragan-2M". The ion current was registered with a Faraday cup (FC). After measurement the current, the bottom of the FC was opened by an electromagnetic system, allowing the beam to pass through, and scanning voltage was applied to deflect the beam by the plates $\alpha 1$ and/or $\beta 1$.

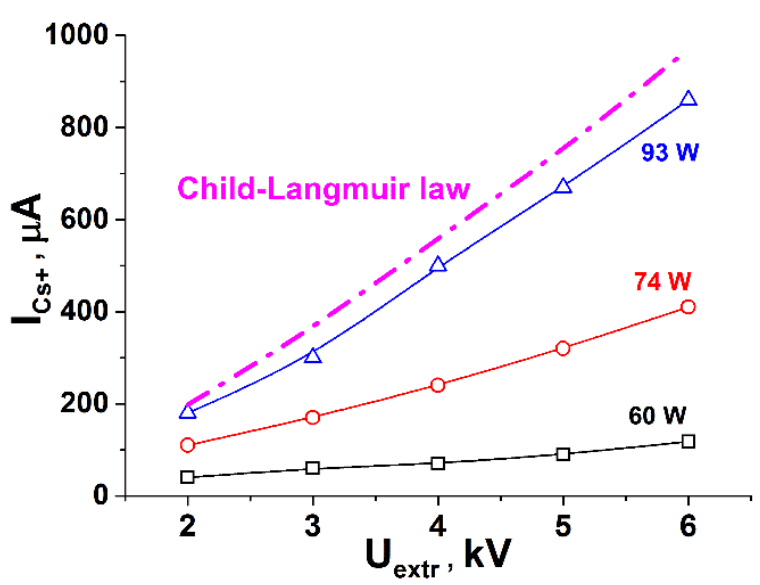

Fig. 3. Volt-ampere characteristics of optimized $\mathrm{Cs}^{+}$ beam for various emitter heating power $P_{\text {heat }}$

The signals from two wire grid detectors were used to determine the beam diameter as a full width at half maximum (FWHM) for various values of the beam current and focusing voltage (Fig. 5). To scan the primary beam across the wire detector, $2 \mathrm{kV}$ output $50 \mathrm{~Hz}$ AC transformer was used. The beam profiles were registered by two sets of wire detectors, \#1 (the distance between wires $-35 \mathrm{~mm}$ ) and \#2 (the distance between wires $-30 \mathrm{~mm}$ ). As the deflecting $\alpha 1$ plates cause some beam distortion by their electric field, the beam diameters $D_{\text {FWHM }}$ were calculated as the average of beam FWHM from both wires of each detector.

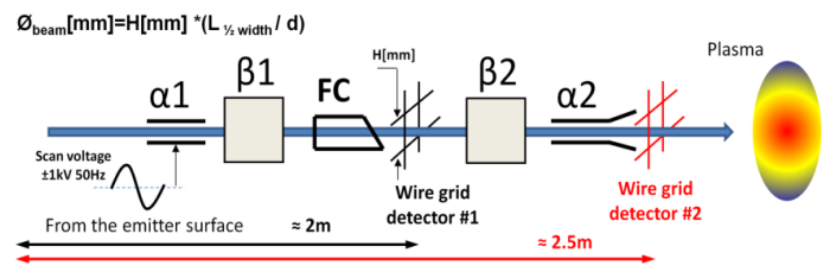

Fig. 4. Primary beam line for control and measurement of the ion beam current and diameter

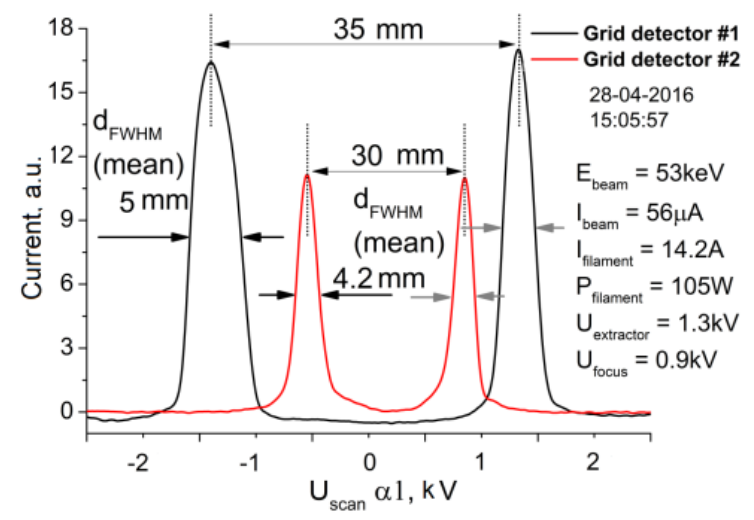

Fig. 5. Beam profile measurements in the "Uragan-2M" injector 
Table 1

Optimal parameters of injection system and $\mathrm{Cs}^{+}$beam

\begin{tabular}{|c|c|c|c|c|}
\hline \multicolumn{5}{|c|}{ for "Uragan-2M", $E_{b}=70 \mathrm{keV}$} \\
\hline $\begin{array}{c}I_{\mathrm{Cs}+}, \\
\mu \mathrm{A}\end{array}$ & $\begin{array}{c}D_{\text {FWHM }}, \\
\text { mm }\end{array}$ & $\begin{array}{c}P_{\text {heat }}, \\
\text { W }\end{array}$ & $\begin{array}{l}U_{\text {extrt }}, \\
\mathrm{kV}\end{array}$ & $\begin{array}{c}U_{\text {focus }}, \\
\mathrm{kV}\end{array}$ \\
\hline 40 & 3.6 & 96 & 1.05 & 2.59 \\
\hline 90 & 4.6 & 96 & 1.79 & 1.93 \\
\hline 140 & 5.5 & 106 & 1.57 & 2.04 \\
\hline 200 & 6.8 & 105 & 2.17 & 2.04 \\
\hline 240 & 9 & 104 & 3.16 & 1.81 \\
\hline
\end{tabular}

Table 1 shows the optimal results for $\mathrm{Cs}^{+}$beam focusing on the lower wire grid detector \# 2 (see Fig. 4) for the HIBP injector of "Uragan-2M" for various current levels. The beam energy for the standard magnetic configuration of "Uragan-2M" was $70 \mathrm{keV}$. The ion current of the $\mathrm{Cs}^{+}$beam varied from 40 to $240 \mu \mathrm{A}$.

The similar scheme was used for the $\mathrm{Cs}^{+}$beam focusing to the wire detector \# 2 for the HIBP-II injector of the TJ-II dual HIBP [4]. Table 2 shows focusing data for the beam current range from 100 to $800 \mu \mathrm{A}$ with the energy $132 \mathrm{keV}$, used for standard magnetic configuration of TJ-II. The current density of the solidstate thermoionic emitter ranged from 0.18 to $1.4 \mathrm{~mA} / \mathrm{cm}^{2}$. The maximal reached value is close to the limit set by the Child-Langmuir law for the plane case:

$$
\begin{gathered}
J_{C L}=\frac{1}{9 \pi}\left(\frac{2 e}{m}\right)^{1 / 2} \frac{U_{\operatorname{extr}^{3} / 2}^{d^{2}}}{J_{C L}\left[\frac{m A}{\mathrm{~cm}^{2}}\right]=1,72\left(\frac{z}{A}\right)^{1 / 2} \frac{\operatorname{Uextr}^{3 / 2}[\mathrm{kV}]}{d^{2}[\mathrm{~cm}]},}
\end{gathered}
$$

where $Z$-ion charge, $A$-ion mass (amu), $U_{\text {extr }}$ - extracting voltage, $d$ - distance between emitter and extractor electrodes. The Child-Langmuir law predicts the beam current density $1.7 \mathrm{~mA} / \mathrm{cm}^{2}$ for $U_{\text {extr }}=6 \mathrm{kV}$ and $d=1.1 \mathrm{~cm}$, so achieved experimental value reaches $82 \%$ of the maximal possible value.

Fig. 6 shows the dependence of the $\mathrm{Cs}^{+}$beam current on the emitter heating power of the TJ-II HIBP II injector. The current was registered by FC at the fixed $U_{\text {extr }}=6 \mathrm{kV}$. Thus, at the explored parameter domain the $\mathrm{mA}$ range of $\mathrm{Cs}^{+}$beam is achieved.

Table 2

Optimal parameters of the $\mathrm{Cs}^{+}$beam and injection system of TJ-II HIBP II, $E_{b}=132 \mathrm{keV}$

\begin{tabular}{|c|c|c|c|c|}
\hline $\begin{array}{c}I_{\mathrm{Cs}+}, \\
\mu \mathrm{A}\end{array}$ & $\begin{array}{c}D_{\text {FWHM, }} \\
\mathrm{mm}\end{array}$ & $\begin{array}{c}P_{\text {heat }}, \\
\mathrm{W}\end{array}$ & $\begin{array}{c}U_{\text {extr }}, \\
\mathrm{kV}\end{array}$ & $\begin{array}{c}U_{\text {focus }}, \\
\mathrm{kV}\end{array}$ \\
\hline 100 & 3 & 67 & 1 & 10 \\
\hline 350 & 6 & 70 & 6 & 2.2 \\
\hline 560 & 6 & 80 & 6 & 2.1 \\
\hline 800 & 6 & 90 & 6 & 2 \\
\hline
\end{tabular}

\section{FOCUSING OF THE PROBING BEAM AT THE SAMPLE VOLUME}

The first experiments were carried out to focus the primary beam in the sample volume aiming for the maximization of the secondary beam at the detector of TJ-II HIBP II.
In a series of reproducible discharges of TJ-II, $U_{\text {focus }}$ was varied in the range $1.2 \ldots 4 \mathrm{kV}$ at the fixed primary ion current $100 \mu \mathrm{A}$. Fig. 7 shows the secondary beam current radial profiles obtained for line-averaged plasma density $(0.55 \pm 0.05) \cdot 10^{19} \mathrm{~m}^{-3}$. The maximum level of the $C s^{2+}$ beam current was obtained with $U_{\text {focus }}=3.5 \mathrm{kV}$ (Fig. 8).

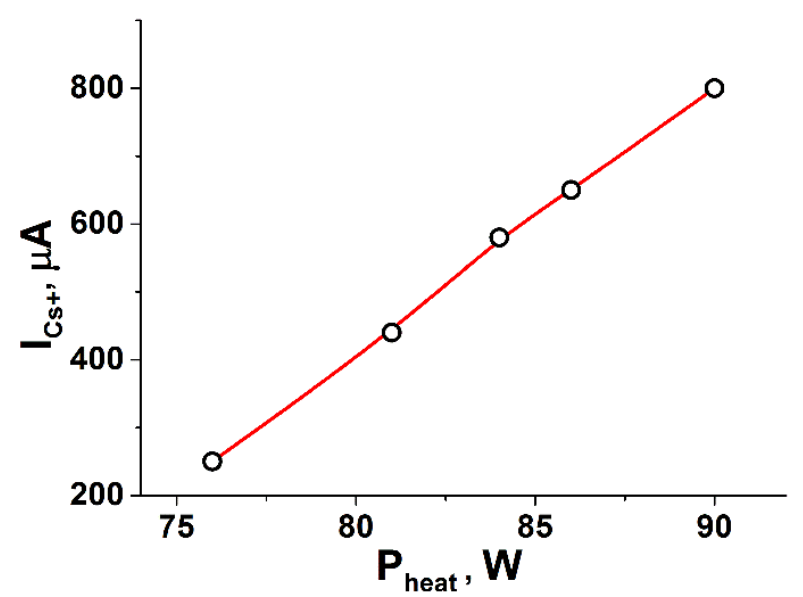

Fig. 6. The dependence of the cesium beam current on the emitter heating power of the TJ-II HIBP II

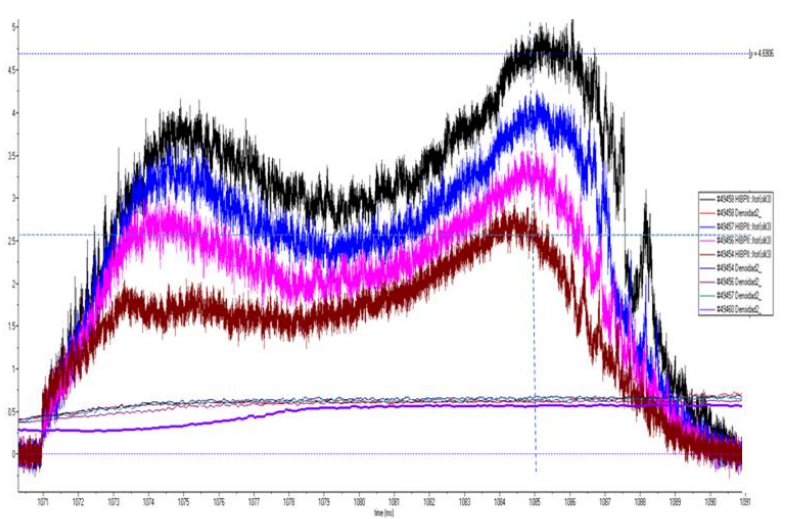

Fig. 7. Radial scan of the $\mathrm{Cs}^{2+}$ secondary beam current for various focusing voltages (marked with colors) in the range $U_{\text {focus }}=1.2 \ldots 4 \mathrm{kV}$ at TJ-II HIBP II

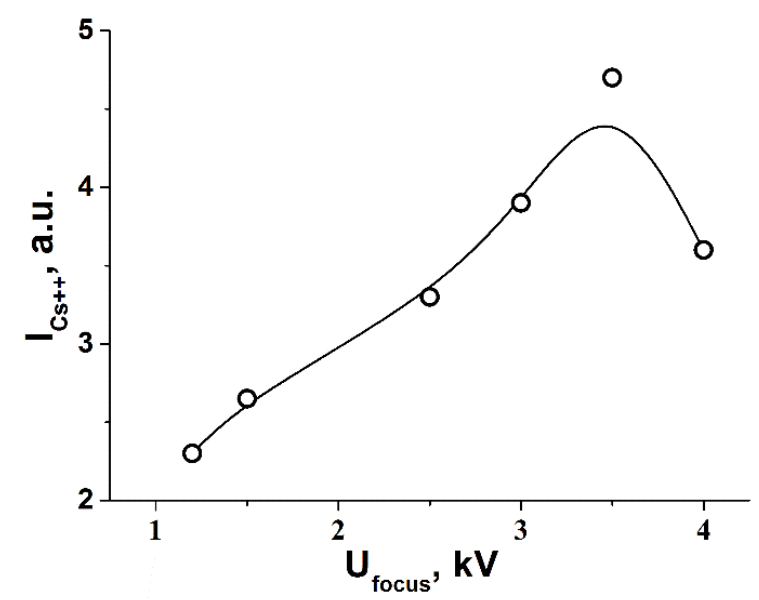

Fig. 8. Dependence of the $\mathrm{Cs}^{2+}$ secondary beam current maximum level on the focusing voltage in TJ-II HIBP II 
The similar optimization of the focusing voltage should be carried out for each primary beam current and energy. Fig. 8 shows a significant effect of the focusing voltage on the secondary beam current, measured by the beam detector of the energy analyzer.

\section{APPLICATION OF THE OPTIMIZED BEAM TO THE TJ-II EXPERIMENT}

Optimization of the beam parameters widens the dual HIBP capabilities. Fig. 9 shows the $\mathrm{Cs}^{2+}$ beam currents of HIBP I (1) and HIBP II (2) obtained with synch ronous scanning mode. SVs periodically move from Low Field Side (LFS) to High Field Side (HFS) and back passing through the plasma centre in the scenario with ECRH (represented by $\mathrm{T}_{\mathrm{e}}$, measured by central chord of ECE radiometer (3)) and NBI heating (4). Line-averaged plasma density time trace is marked by 5 , the combined ECR+NBI heating phase is high lighted by green rectangle. Primary $\mathrm{Cs}^{+}$beam current in the HIBP I was $130 \mu \mathrm{A}$, and in the HIBP II $-230 \mu \mathrm{A}$. Figure shows that the density raise due to NBI fueling causes the decrease of the secondary beam current signal due to the beam attenuation at the HFS while in the LFS signal may even raise due to the raise of the local density in the very edge. This data forms the basis for the further density profile reconstruction [7].

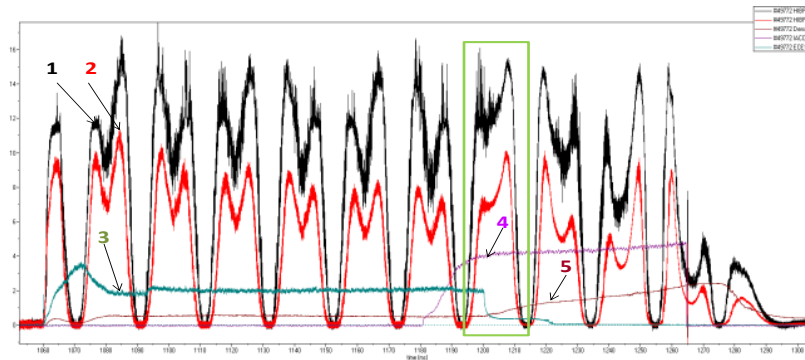

Fig. 9. TJ-II plasma scenario with combined ECR+NBI heating and dual HIBP operation in the synchronous scanning mode, \#49772

Figs. 10, 11 show the power spectral densities (PSD) of the plasma potential signals measured by HIBP I and HIBP II systems in the scanning mode, as well as their coherence (Fig. 12) in the phase of combined heating. Figs. 10, 11 show clearly the Alfvéneigen mode frequency evolution with density, conventionally observed in TJ-II with HIBP I [7, 8] and recently with HIBP II [9].

Fig. 12 confirms the global character of this mode (A). On top of that, the new mode (B) was observed in the wider frequency area previously unexplored due to the beam current limitations. This mode of the plasma potential oscillations occurs in the range of $500 \ldots 600 \mathrm{kHz}$ and located practically in the plasma centre. It contrasts to the lower frequency mode A, which is extended over the whole core region. Remarkably, the mode Bis excited in the combined ECR+NBI heating phase only.

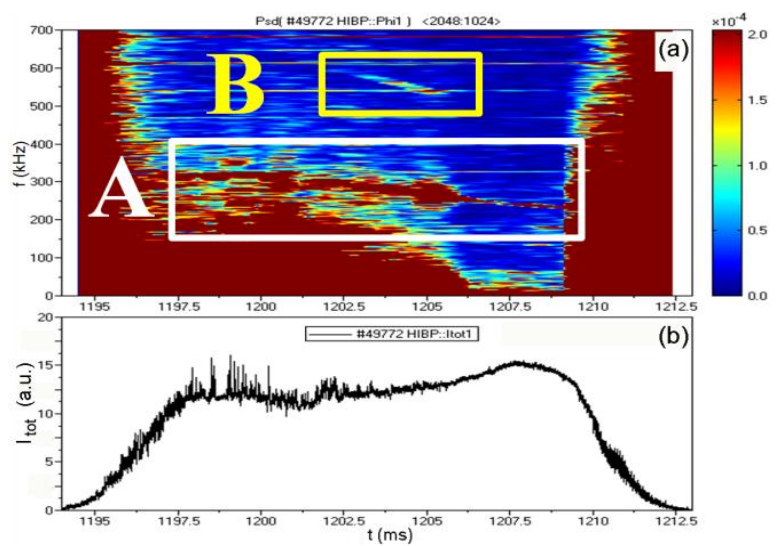

Fig. 10. TJ-II \#49772, HIBP I data: a - PSD of plasma potential; $b$-total current of the $C s^{2+}$ secondary beam. A - conventionally observed Alfvéneigen mode; $B$ - higher-frequency mode

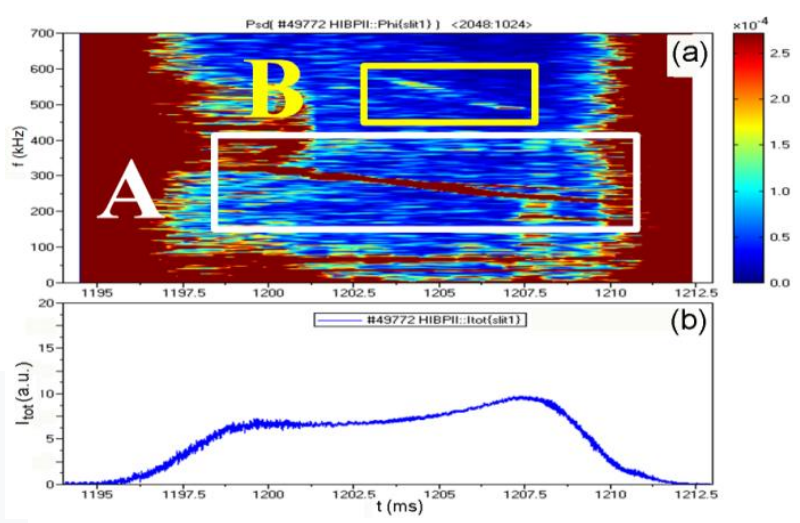

Fig. 11. TJ-II \#49772 HIBP II data: a - PSD of plasma potential; $b$-total current of the $C s^{2+}$ secondary beam

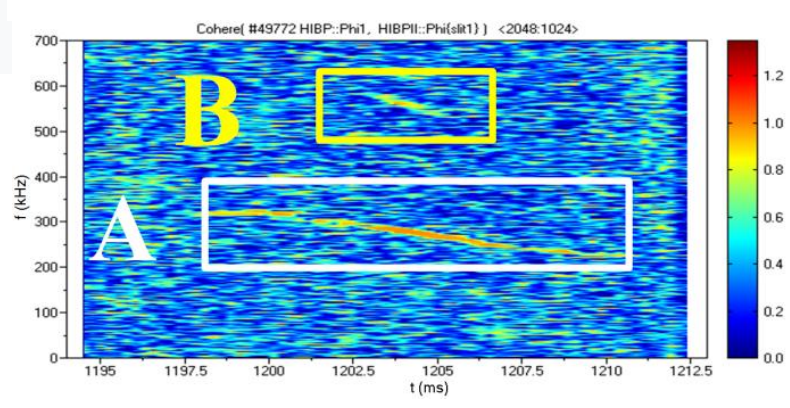

Fig. 12. Coherence between potential signals of HIBP I and HIBP II, \#49772

\section{CONCLUSIONS}

The possibility of forming $\mathrm{Cs}^{+}$probing beams with a current up to $0.8 \mathrm{~mA}$ is shown. Optimization of the $\mathrm{Cs}^{+}$ beam on the dual HIBP in TJ-II expanded its diagnostic capabilities and made it possible to observe the plasma potential fluctuations with a frequency of up to $600 \mathrm{kHz}$. The technique for probing ion source production may be used for HIBP projects on W7-X [10], T-15MD [11, 12], Globus-2M, and other fusion devices. 


\section{ACKNOWLEDGEMENTS}

This work has been carried out within the framework of the EUROfusion Consortium and has received funding from the Euratom research and training programme 2014-2018 and 2019-2020 under grant agreement No. 633053. The views and opinions expressed herein do not necessarily reflect those of the European Commission. Work performed under EUROfusion WP S1 and WP EDU, the STCU project P-507. Analysis of beam features and Alfvéneigen modes done by Kurchatov team was supported by Russian Science Foundation project 19-12-00312. A.V. Melnikov was partly supported by the Competitiveness Program of NRNU MEPhI.

\section{REFERENCES}

1. F.C. Jobes, R.L. Hickok. A direct measurement of plasma space potential // Nuclear Fusion. 1970, v. 10, p. 195-197.

2. Yu.N. Dnestrovskij, A.V. Melnikov, L.I. Krupnik, I.S. Nedzelskij. Development of heavy ion beam probe diagnostics // IEEE Transaction Plasma Science. 1994, v. 22 , p. $310-331$.

3. O.D. Komarov, O.O. Chmyga, V.V. Chechkin, et al. Estimations of Plasma Potential and Density by the Heavy Ion Beam Probing Diagnostics on the Uragan2M Torsatron // Problems of Atomic Science and Technology. Series «Plasma Physics». 2016, № 6, p. 306-309.

4. A.I. Zhezhera et al. New Capabilities of Plasma Potential and Density Measurements Using a Dual Heavy Ion Beam Probing (HIBP) Diagnostic in them TJ-II Stellarator // Problems of Atomic Science and
Technology. Series «Plasma Physics». 2017, № 1, p. 261-264.

5. A.V. Melnikov. Electric Potential in Toroidal Plasmas // Springer Nature Switzerl and AG. 2019, p. 240.

6. L.I. Krupnik, A.D. Komarov, A.S. Kozachok, A.V. Melnikov, I.S Nedzelskij. High-Intensity Thermoionic Alkali Ion Sources for Plasma Diagnostics // IEEE Transaction Plasma Science. 2008, v. 36, p. $1536-1545$.

7. Ph.O. Khabanov, A.A. Chmyga, et al. Density profile reconstruction using HIBP in ECRH plasmas in the TJII stellarator // Journal of Instrumentation. 2019, v. 14, p. C09033.

8. A.V. Melnikov, L.I. Krupnik, et al. Internal measurements of Alfvén eigenmodes with heavy ion beam probing in toroidal plasmas // Nuclear Fusion. 2010, v. 50, p. 084023

9. A.V. Melnikov, L.I. Krupnik, et al. Heavy ion beam probing - diagnostics to study potential and turbulence in toroidal plasmas // Nuclear Fusion. 2017, v. 57, p. 072004.

10. S.V. Perfilov, A.V. Melnikov, L.I. Krupnik, H.J. Hartfuss. Applicability of heavy ion beam probing for stellarator W7-X // Fusion Science and Technology. 2007, v. 51, № 1, p. 38-45.

11. A.V. Melnikov, A.V. Sushkov, A.M. Belov, et al. Physical Program and Diagnostics of the T-15 Upgrade Tokamak // Fusion Engineering Design. 2015, v. 96-97, p. 306-310.

12. M.A. Drabinskiy et al. Conceptual design of the heavy ion beam probe diagnostic for the T-15MD tokamak // Journal of Instrumentation. 2019, v. 14, p. 11027.

Article received 05.10.2020.

\title{
ВЫСОКОИНТЕНСИВНЫЕ ПУЧКИ ИОНОВ ЦЕЗИЯ ДЛЯ ДИАГНОСТИКИ С ПОМОЩЬЮ ЗППТИ
}

\author{
Л.И. Крупник, Х. Баркала, А.А. Чмыга, Г.Н. Дешко, М.А. Драбинский, Л.Г. Елисеев, К. Идальго, \\ Ф.О. Хабанов, Н.К. Харчев, С.М. Хребтов, А.Д. Комаров, А.С. Козачек, А.В. Мельников, А. Молинеро, \\ Х.Л. де Паблос и коллектив стелларатора ТJ-II
}

Цель исследования - расширить возможности диагностики с помощью зондирования плазмы пучком тяжелых ионов (ЗППТИ). ЗППТИ - это уникальная диагностика, способная измерять потенциал, плотность плазмы и их флуктуации, а также флуктуации полоидального магнитного поля в центре и периферии плазмы. Чувствительность диагностики определяется уровнем выходного сигнала относительно инструментального шума. Уровень тока зондирующего пучка должен быть как можно более высоким, особенно для измерений на периферии с низким выходным сигналом из-за низкой плотности плазмы, а также в центре, где пучок ослабляется из-за высокой плотности плазмы. Эксперименты по оптимизации показали возможность формирования ионного пучка в диапазоне тока $40 \ldots 800$ мкА.

\section{ВИСОКОІНТЕНСИВНІ ПУЧКИ ІОНІВ ЦЕЗІЮ ДЛЯ ДІАГНОСТИКИ ЗА ДОПОМОГОЮ ЗППВІ}

\author{
Л.І. Крупнік, Х. Баркала, О.О. Чмига, Г.М. Дешко, М.А. Драбінський, Л.Г. Слісєєв, К. Ідальго, \\ Ф.О. Хабанов, М.К. Харчев, С.М. Хребтов, О.Д. Комаров, О.С. Козачок, О.В. Мельніков, А. Молінеро, \\ Х.Л. де Паблос та колектив стелларатора ТЈ-ІІ
}

Мета дослідження - розширити можливості діагностики за допомогою зондування плазми пучком важких іонів (ЗППВІ). ЗПІІВІ - це унікальна діагностика, здатна вимірювати потенціал, густину плазми і їх флуктуації, а також флуктуації полоідального магнітного поля в центрі та периферії плазми. Чутливість діагностики визначається рівнем вихідного сигналу, щодо інструментального шуму. Рівень струму зондувального пучка повинен бути якомога більш високим, особливо для вимірювань на периферії з низьким вихідним сигналом через низьку густину плазми, а також у центрі, де пучок послаблюється через високу густину плазми. Експерименти 3 оптимізації показали можливість формування іонного пучка в діапазоні струму $40 \ldots 800$ мкА. 